\title{
Pertumbuhan Bibit Pisang Ekspor Cavendish Asal Kultur Jaringan di Nurseri dengan Teknologi Pemberian Kosarine
}

\author{
Ratna Nirmala ${ }^{1}$, Ratna Shanti ${ }^{2}$ \\ 1,2Program Studi Agroekoteknologi Fakultas PertanianUniversitas Mulawarman \\ Jalan Pasir Belengkong Gunung Kelua Samarinda \\ 1email: ratnanirmala1948@gmail.com
}

\begin{abstract}
The aim of this research are 1) to determine the effect of liquid organic fertilizer kosarine to the growth of export Cavendish banana seedling in nursery from tissue culture and 2) to find the proper concentration of kosarine to the bets growth of banana seedlings. It was conducted at Kenyah street, Sempaja Village North Samarinda, starting from August until October 2017. This research used Randomized Completely Design (R.C.D) with four treatment concentration kosarine liquid organic fertilizer, consisting of $0 \mathrm{ml}$ kosarine/l water as control (KO), $10 \mathrm{ml}$ kosarine/l water (K1), $20 \mathrm{ml}$ kosarine/l water (K2), and $30 \mathrm{ml}$ kosarine/l water (K3). Each treatment were replicated in six times, so that all treatments were 24 polybags. The polybag contained top soil mixed goat manure with ratio $4: 1$. One seedling of banana was planted in one polybag. Result of the research showed that the effect of several concentration of kosarine on the increasing of height seedling was significant offect on the age of 3 weeks after planting (WAP), but no significant on the age 5, 7, and 9 $W A P$. In the variable increasing number of leaves, kosarine concentration treatment were not significant effect on 3 and 5 WAP, but the significantly different on 7 and 9 $W A P$. In the variable increasing longest of leaves, effect of kosarine significant on 3 and 9 WAP, but was not significant different on 5 and 7 WAP. In the variable increasing widest of leaves of banana seedling, effect of kosarine were significant different on the all ages 3, 5, 7, and 9 WAP. In the variable increasing diameter of stem banana seedling, the effect of kosarine was significant different on the age of 9 WAP. The effect of kosarine concentration treatment on the all variable and the all ages observation, whether significant or not signinificant, there were a tendencious at $10 \mathrm{ml}$ kosarine/l water (K1) to perform better result than the higher concentration and control.
\end{abstract}

Keywords: Export Cavendish Banana Seedlings, Tissue Culture, Kosarine Giving Technology.

ABSTRAK
Penelitian ini bertujuan untuk mengetahui 1) pengaruh pupuk organik cair kosarine
terhadap pertumbuhan bibit pisang ekspor Cavendish asal kultur jaringan di nurseri
dan 2) konsentrasi pupuk organik cair kosarine yang tepat dalam mempengaruhi
pertumbuhan bibit pisang yang terbaik. Penelitian dilaksanakan pada bulan Agustus
sampai Oktober 2017. di lokasi lahan pada Jalan Kenyah Sempaja, Kelurahan
Sempaja Kecamatan Samarinda Utara. Rancangan percobaan yang digunakan
adalah Rancangan Acak Lengkap (RAL) terdiri atas empat perlakuan konsentrasi
POC kosarine yang masing-masing diulang enam kali, yaitu : 0 ml/L air sebagai
control (KO), $10 \mathrm{ml} / \mathrm{L}$ air (K1), $20 \mathrm{ml} / \mathrm{L}$ air (K2), dan $30 \mathrm{ml} / \mathrm{L}$ air (K3). Sehingga
terdapat 24 populasi bibit tanaman, yang masing-masing ditanam pada polibag yang
berisi campuran top soil dan pupuk kandang kambing dengan rasio $4: 1$. Hasil
penelitian menunjukkan bahwa pengaruh berbagai konsentrasi POC kosarineterhadap
pertambahan tinggi terlihat memberikan pengaruh nyata pada umur 3 Minggu Setelah
Tanam (MST), namun tidak memberikan pengaruh nyata pada umur 5 , 7 , dan $9 \mathrm{MST}$.
Pada variabel pertambahan jumlah daun, perlakuan konsentrasi kosarine memberikan
pengaruh yang tidak nyata pada umur 3 dan $5 \mathrm{MST}$, namun berpengaruh nyata pada
umur 7 dan 9 MST. Pada variabel pertambahan panjang daun terpanjang, perlakuan
konsentrasi kosarine memberikan pengaruh yang nyata pada umur 3 dan 9 MST,
namun berpengaruh tidak nyata pada umur 5 dan 7 MST. Pada variabel
pertambahan lebar daun terlebar bibit pisang, perlakuan konsentrasi kosarine 
memberikan pengaruh yang nyata pada semua umur 3, 5, 7, dan 9 MST. Pada variabel pertambahan diameter batang bibit pisang, perlakuan konsentrasi kosarine memberikan pengaruh nyata pada umur 9 MST. Pengaruh perlakuan konsentrasi kosarine terhadap semua variabel dan semua umur pengamatan, baik berpengaruh nyata maupun yang tidak berpengaruh nyata, cenderung pada konsentrasi $10 \mathrm{ml} / \mathrm{L}$ air (K1) pengaruhnya lebih baik dibandingkan pada konsentrasi yang lebih tinggi dan kontrol.

Kata Kunci : Bibit Pisang Ekspor Cavendish, Kultur Jaringan, Teknologi Pemberian Kosarine.

\section{Pendahuluan}

\subsection{Latar Belakang}

Pisang merupakan produk hortikultura yang buahnya disenangi masyarakat dunia, sehingga permintaan pasar setiap tahunnya meningkat, seiring dengan semakin meningkatnya jumlah penduduk ( Wong, Suhaimi, Fatimah, 2016). Di Indonesia tanaman tersebut banyak jenisnya dan tersebar di seluruh nusantara. Salah satu jenis diantaranya yaitu pisang cavendish yang merupakan komoditi ekspor dari Pulau Jawa dan Maluku, namun di Pulau Kalimantan, khususnya di Provinsi Kalimantan Timur, jenis pisang ini belum begitu dikenal masyarakat petani.

Buah pisang cavendish mengandung nilai gizi yang cukup tinggi. Setiap $100 \mathrm{~g}$ : karbohidrat $22,2 \mathrm{~g}$, protein $1,1 \mathrm{~g}$, lemak $0,2 \mathrm{~g}$, air $75,7 \%$ abu $0,8 \mathrm{~g}$. Selain itu juga mengandung vitamin A (SI) 5,1, vitamin C $20 \mathrm{mg}$, thiamin 2,6 mg, Ribofilavin 5,3 mg dan niacin 4,8 mg. (Suhardiman, 1997). Rasa buah pisang ini mirip pisang Ambon hanya saja strukturnya sedikit lebih padat. Buah ini sangat baik bagi kesehatan tubuh manusia, karena dapat membantu memperlacar sistem pencernaan. Selain itu karena kandungan lemaknya yang rendah baik untuk diet kolestrol.

Untuk meningkatkan komoditi ekspor hortikultura Indonesia, sudah saatnya Kalimantan Timur pun harus turut sebagai eksportir komoditi ini, dengan menumbuh kembangkan pisang jenis cavendish tersebut. Langkah awal yang harus ditempuh yaitu mensosialisasikan pisang ini sekaligus teknik budidayanya ke petani, yang sebelumnya harus dikaji dulu melalui riset-riset. Agar terjamin sifat genetik bibit tanamannya maka sebaiknya digunakan bibit pisang cavendish asal kultur jaringan.

Misi ini merupakan salah satu kewajiban Tri Dharma Prguruan Tinggi yang diemban oleh staf pengajar, terutama yang mendalami teknologi kultur jaringan untuk memproduksi bibit melalui laboratorium kultur jaringan Fakultas Pertanian Universitas Mulawarman. Tahap-tahap riset yang harus dilaksanakan yaitu produksi plantlet (bibit tanaman mini) kemudian diaklimatisasi yang merupakan proses adaptasi bibit ke lingkungan luar. Selanjutnya tanam di Nurseri, kemudian pindah tanam ke lapangan sampai berproduksi. 
Riset produksi bibit di laboratorium telah dilaksanakan oleh peneliti yang menekuni penelitian tentang pisang sampai aklimatisasi, namun teknik pemeliharaan di nurseri belum diteliti. Oleh karena itu perlu penelitian tentang pasca aklimatisasi di nurseri, sebelum dipindah tanam ke lapangan. Teknik budidaya bibit ini memegang kunci keberhasilan aplikasi teknik kultur jaringan di bidang pertanian.

Pertumbuhan dan produksi tanaman dipengaruhi oleh faktor genetik dan lingkungan tumbuh tanaman. Oleh karena itu walaupun sifat ginetik pisang asal kultur jaringan tersebut baik, namun harus diperhatikan pula kesuburan tanahnya, sebagai tempat tumbuh tanaman agar bibit pisang asal kultur jaringan ini dapat tumbuh subur dan tegar, sedangkan telah diketahui bahwa tanah di Kalimantan Timur didominasi oleh tanah Ultisol yang kesuburannya rendah baik kandungan unsur hara makro maupun mikronya (Shanti, 2015), sehingga media tumbuh perlu diberikan perlakuan teknologi pemupukan.

Bahan pupuk yang dipakai ada yang organik dan ada pula yang anorganik, namun petani saat ini cenderung menggunakan pupuk organik yang ramah lingkungan, baik yang berasal dari limbah pertanian maupun ternak, berupa kotoran padat ataupun cair salah satu diantaranya yaitu kosarine berasal dari urin sapi yang telah dibuat melalui proses bioteknologi. Kosarine mengandung unsur hara makro dan mikro: $\mathrm{N}, \mathrm{P}, \mathrm{K}, \mathrm{Ca}, \mathrm{Mg}, \mathrm{Mn}$, $\mathrm{Cu}, \mathrm{Fe}, \mathrm{Zn}$ dan Na, pHnya 7,5(label formula dalam Nirmala 2013) Anty dalam Suharman, 2008 menyatakan bahwa pupuk organik yang berasal dari urin ternak sapi mengandung hormon Indole Acetie Acid (IAA). Hormon ini dapat merangsang pertumbuhan tanaman asal digunakan dalam konsentrasi yang tepat. Sesuai yang dinyatakan (Wareing dan Phillips, 1981) hormon tumbuh dalam konsentrasi yang rendah bersifat mensimulir, sedangkan dalam konsentrasi yang tinggi besifat menghambat, bahkan dapat mematikan, sehingga penggunaannya harus dalam kosentrasi yang tepat.

\subsection{Tujuan}

Tujuan dari penelitian ini adalah:

a. Mengetahui pengaruh pupuk organik cair kosarine terhadap pertumbuhan bibit pisang ekspor Cavendish asal kultur jaringan di nurseri dan

b. mengetaui konsentrasi pupuk organik cair kosarine yang tepat dalam mempengaruhi pertumbuhan bibit pisang yang terbaik.

\subsection{Manfaat}

Memberikan informasi kepada petani atau yang berminat tentang teknik budidaya penelitian pisang pasca aklimatisasi yang diberi pupuk organik cair kosarine yang ramah lingkungan dalam konsentrasi yang tepat, agar bibitnya subur dan tegar. 


\section{Metode Penelitian}

\subsection{Waktu dan Tempat Penelitian}

Penelitian ini dilaksanakan mulai dari Bulan Agustus sampai Oktober 2017. Terhitung sejak persiapan bibit pisang pasca aklimatisasi sampai akhir pengamatan bibit tanaman di nurseri. Penelitan dilaksanakan di Sempaja Kecamatan Samarinda Utara.

\subsection{Bahan dan Alat yang Digunakan}

Bahan penelitian pisang Cavendish pasca aklimatisasi asal kultur jaringan, pupuk organik cair kosarine, polibag, top soil dan pupuk kandang kambing, fungisida, insetisida.

Alat yang digunakan yaitu cangkul, meteran, timbangan, gelas ukur, camera, gembor, ember, arit, alat tulis menulis dan lain-lain.

\subsection{Pelaksanaan Penelitian dan Pemeliharaan}

Bibit pisang cavendish pasca aklimatisasi kultur jaringan dipindah tanamkan ke polybag yang telah diisi dengan top soil yang dicampur dengan pupuk kandang yang telah matang dengan rasio 4:1. Peletakan bibit tanaman sesuai dengan denah percobaan yang dilakukan dengan pengacakan. Bibit diberikan pupuk seminggu sekali, sesuai dengan perlakuan yang diberikan. Pemberian pupuk dilakukan pada sore hari. Penyiraman dan pengendalian hama dan penyakit dilaksanakan sesuai dengan situasi dan kondisi, dilingkungan penelitian.

\subsection{Rancangan Percoban}

Penelitian dilaksanakan dengan menggunakan Rancangan Acak Lengkap (RAL) dengan factor tunggal yaitu perlakuan kosarine dengan empat taraf yaitu: $0 \mathrm{ml} / \mathrm{l}$ air sebagai control (Ko) :10 ml/l air (K1) :20 ml// air (K2) dan $30 \mathrm{ml} / \mathrm{l}$ air (K3) masing-masing perlakuan diulang enam kali, sehingga terdapat 24 polibag tanaman.

\subsection{Parameter yang diamati}
a. Pertambahan tinggi bibit tanaman
b. Pertambahan jumlah daun
c. Pertambahan panjang yang terpanjang
d. Pertambahan lebar daun yang terlebar
e. Pertambahan diameter batang

Pengamatan dan pengambilan data dilakukan dengan interval 2 minggu sekali, kecuali pertambahan diameter batang hanya pada awal dan akhir penelitian. Data dianalisis dengan Analisis Sidik Ragam dan apabila terdapat perbedan yang nyata, maka dilanjutkan dengan uji BNT $5 \%$

\section{Hasil dan Pembahasan \\ Pertambahan Tinggi Bibit}


Hasil sidik ragam menunjukkan bahwa perlakuan konsentrasi Pupuk Organik Cair (POC) kosarine berpengaruh nyata terhadap pertambahan tinggi bibit Pisang Cavendish asal kultur jaringan di nurseri pada umur 3 Minggu Setelah Tanam (MST), namun tidak berpengaruh nyata pada umur 5, 7, dan 9 MST. Rata-rata pertambahan tinggi bibit dapat dilihat pada Tabel 1.

Tabel 1 menunjukkan bahwa pengaruh konsentrasi kosarine hanya nyata pada pertambahan tinggi bibit pisang asal kultur jaringan di nurseri pada umur 3 MST, sehingga dilanjutkan dengan uji BNT 5\%. Perlakuan K1 (10 ml/L air) menghasilkan pertambahan tinggi 10,53 cm, K2 (20 ml/L air) menghasilkan $9,13 \mathrm{~cm}, \mathrm{~K} 3(30 \mathrm{ml} / \mathrm{L}$ air) menghasilkan $7,98 \mathrm{~cm}$. K1, K2, K3 saling tidak berbeda nyata, namun berbeda dengan kontrol K0 (0 $\mathrm{ml} / \mathrm{L}$ air) yang menghasilkan $4,60 \mathrm{~cm}$. Pertambahan tinggi yang tertinggi pada perlakuan K1 (10 ml/L air) yaitu $10,53 \mathrm{~cm}$.

Tabel 1. Rata-rata Pertambahan Tinggi Bibit Pisang Ekspor Cavendish Asal Kultur Jaringan di Nurseri dengan Teknologi Pemberian Berbagai Konsentrasi Kosarine $(\mathrm{cm})$.

\begin{tabular}{ccccc}
\hline Perlakuan Konsentrasi & \multicolumn{4}{c}{ Pertambahan Tinggi Bibit Pada Umur } \\
\cline { 2 - 5 } Kosarine (K) & $3 \mathrm{MST}$ & $5 \mathrm{MST}$ & 7 MST & $9 \mathrm{MST}$ \\
\hline K0 (0 ml/L air) & $4.60 \mathrm{a}$ & 12.03 & 13.53 & 14.77 \\
K1 (10 ml/L air) & $10.53 \mathrm{a}$ & 15.22 & 16.45 & 17.57 \\
K2 (20 ml/L air) & $9.13 \mathrm{~b}$ & 13.50 & 14.82 & 15.83 \\
K3 (30 ml/L air) & $7.98 \mathrm{~b}$ & 12.48 & 15.92 & 14.63 \\
\hline
\end{tabular}

Keterangan: Angka-angka yang diikuti oleh huruf yang sama pada jalur yang sama berarti tidak berbeda sama.

Pengaruh perlakuan konsentrasi kosarine pada pertambahan tinggi bibit pisang asal kultur jaringan pada umur 5, 7, dan 9 MST tidak berpengaruh nyata. Namun dari tabel data ini menunjukkan pertambahan tinggi bibit yang tertinggi pada perlakuan K1 (10 $\mathrm{ml} / \mathrm{L}$ air) dibandingkan perlakuan lain. Semakin meningkatnya konsentrasi kosarine yang diberikan, pengaruh hasilnya bertendensi semakin menurun, tetapi hasil perlakuan ini masih lebih baik dibandingkan kontrol.

Pertumbuhan dan perkembangan tinggi bibit pisang yang dihasilkan, mulai umur 3 sampai 9 MST di nurseri terlihat pada Gambar 1. 


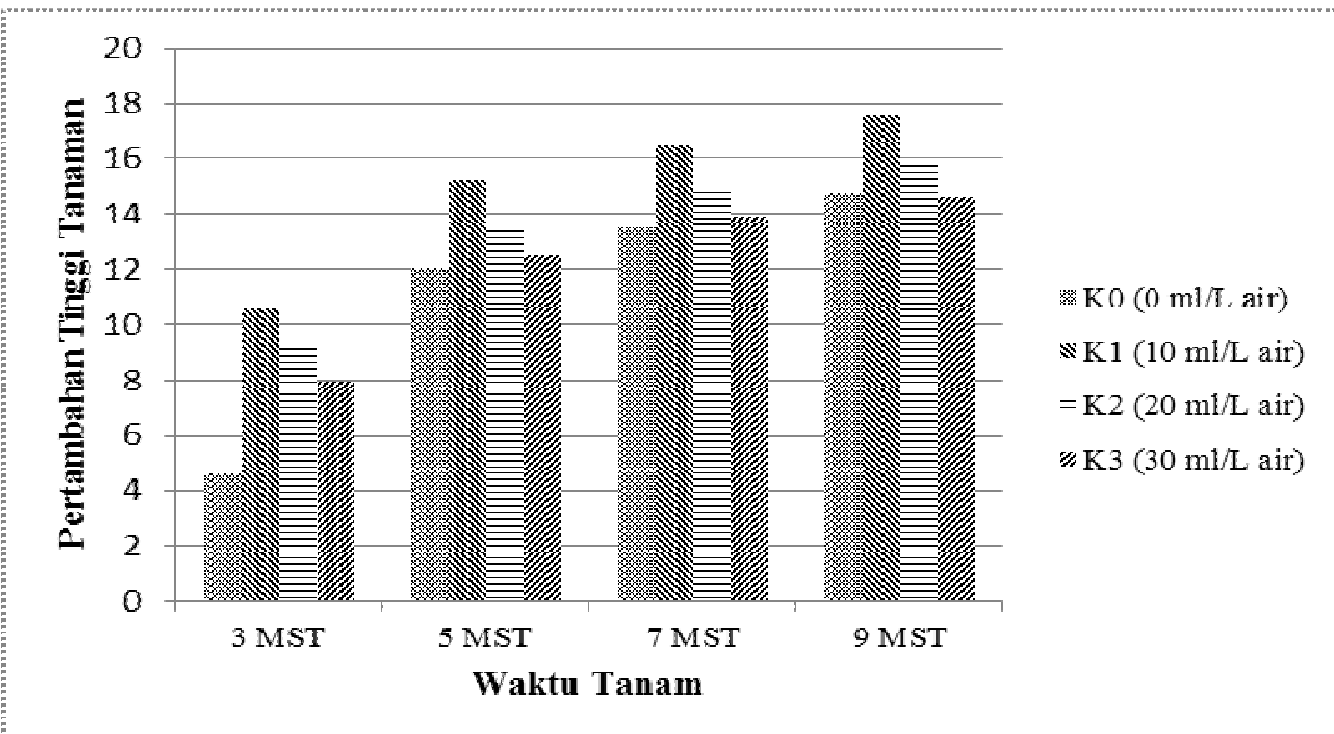

Gambar 1. Histogram Rata-rata Pertambahan Tinggi Bibit Pisang Ekspor Cavendish Asal Kultur Jaringan di Nurseri dengan Teknologi Pemberian Berbagai Konsentrasi Kosarine.

Hal ini diduga yang paling berperan pengaruhnya pada perlakuan kosarine ini adalah kandungan urin sapi yang mengandung hormon IAA dibandingkan unsur hara makro dan mikronya, sehingga pada perlakuan $\mathrm{K} 1$ (10 ml/L air) mampu menghasilkan pertambahan tinggi bibit pisang yang tertinggi dibandingkan pada konsentrasi yang lebih tinggi yaitu $\mathrm{K} 2$ (20 ml/L air) dan $\mathrm{K} 3(30 \mathrm{ml} / \mathrm{L}$ air). Keadaan ini sesuai dengan pendapat Wattimena (1988), yang menyatakan bahwa hormon tumbuh mempunyai sifat yang dapat menstimulir pertumbuhan dalam konsentrasi yang rendah dan bersifat menghambat, malah dapat mematikan pada konsentrasi yang tinggi. IAA termasuk golongan hormon auksin yang dapat meningkatkan pertumbuhan tinggi tanaman. Sesuai dengan yang dikatakan Wareing and Phillips (1981), bahwa auksin berperan untuk memperbesar dan memperpanjang sel tanaman, sehingga mampu meningkatkan tinggi tanaman.

\section{Pertambahan Jumlah Daun}

Hasil sidik ragam menunjukan bahwa perlakuan konsentrasi Pupuk Organik Cair (POC) kosarine berpengaruh tidak nyata terhadap pertambahan jumlah daun bibit Pisang Cavendish asal kultur jaringan di nurseri pada umur 3 dan 5 Minggu Setelah Tanam (MST), namun berpengaruh nyata pada umur 7 dan 9 MST. Rata-rata pertambahan jumlah daun bibit dapat dilihat pada Tabel 2.

Tabel 2. Rata-rata Pertambahan Jumlah Daun Bibit Pisang Ekspor Cavendish Asal Kultur Jaringan di Nurseri dengan Teknologi Pemberian Berbagai Konsentrasi Kosarine (helai).

\begin{tabular}{ccccc}
\hline Perlakuan Konsentrasi & \multicolumn{4}{c}{ Pertambahan Tinggi Bibit Pada Umur } \\
\cline { 2 - 5 } Kosarine (K) & $3 \mathrm{MST}$ & $5 \mathrm{MST}$ & $7 \mathrm{MST}$ & $9 \mathrm{MST}$ \\
\hline $\mathrm{K} 0(0 \mathrm{ml} / \mathrm{L}$ air $)$ & 1.00 & 1.83 & $2.17 \mathrm{a}$ & $2.50 \mathrm{a}$ \\
$\mathrm{K} 1(10 \mathrm{ml} / \mathrm{L}$ air $)$ & 1.67 & 2.67 & $3.33 \mathrm{~b}$ & $3.83 \mathrm{~b}$ \\
$\mathrm{~K} 2(20 \mathrm{ml} / \mathrm{L}$ air $)$ & 1.50 & 2.00 & $2.33 \mathrm{a}$ & $2.67 \mathrm{a}$ \\
K3 $(30 \mathrm{ml} / \mathrm{L}$ air $)$ & 1.17 & 1.50 & $1.83 \mathrm{a}$ & $2.17 \mathrm{a}$ \\
\hline
\end{tabular}

Ket :Angka-angka yang diikuti oleh huruf yang sama pada jalur yang sama berarti tidak berbeda sama. 
Data Tabel 2 menunjukkan bahwa konsentrasi kosarine tidak berpengaruh nyata terhadap pertambahan jumlah daun bibit pisang pada umur 3 dan 5 MST. Sedangkan pada umur 7 dan 9 MST berpengaruh nyata. Perlakuan K1 (10 ml/L air) berbeda nyata dibandingkan kontrol dan perlakuan $\mathrm{K} 2(20 \mathrm{ml} / \mathrm{L}$ air $)$ dan $\mathrm{K} 3(30 \mathrm{ml} / \mathrm{L}$ air $)$, namun ketiganya kontrol, K2 dan K3 tidak berbeda nyata.

Semua data menunjukkan bahwa perlakuan K1 (10 ml/L air) memberikan hasil pertambahan jumlah daun bibit yang terbanyak pada semua umur pengamatan dibandingkan semakin meningkatnya pemberian konsentrasi kosarine, memberikan pengaruh hasil yang semakin menurun.

Pertumbuhan dan perkembangan jumlah daun bibit pisang yang dihasilkan mulai umur 3 sampai 9 MST di nurseri, terlihat pada Gambar 2.

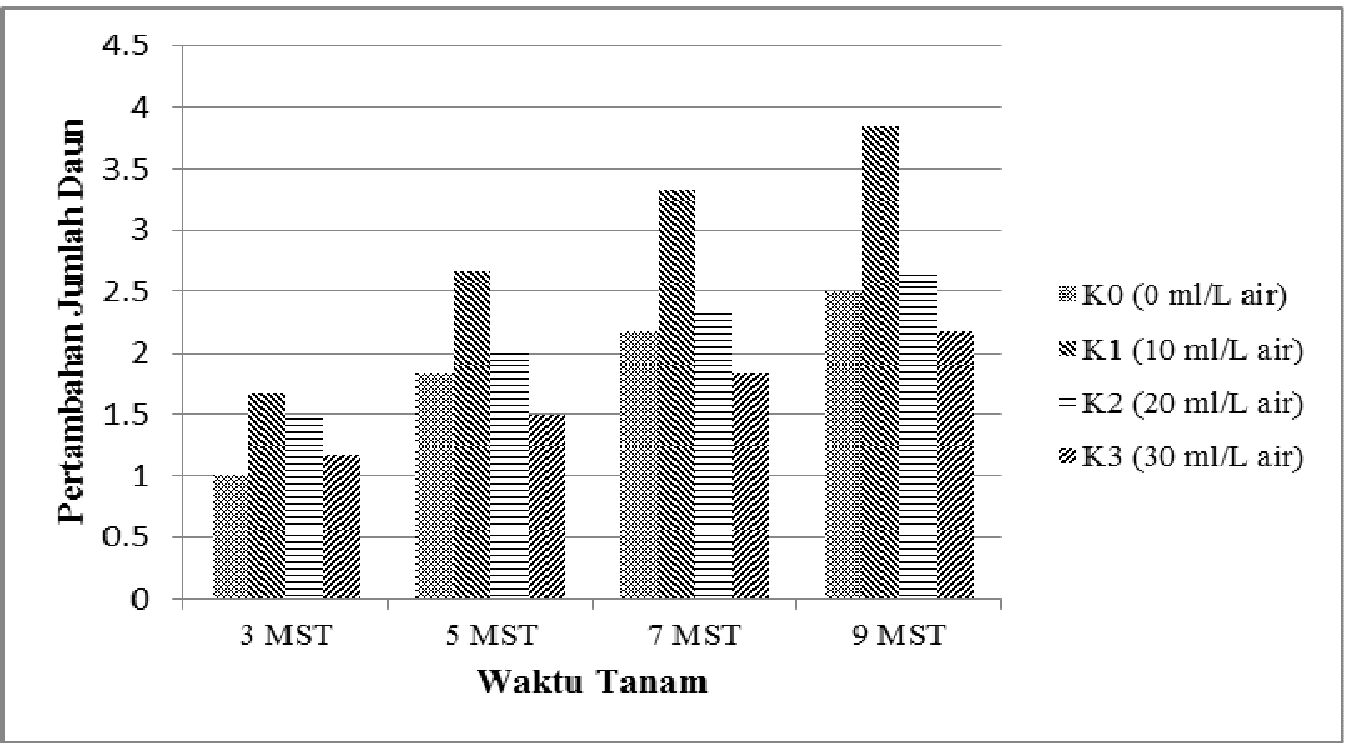

Gambar 2. Histogram Rata-rata Pertambahan Jumlah Daun Bibit Pisang Ekspor Cavendish Asal Kultur Jaringan di Nurseri dengan Teknologi Pemberian Berbagai Konsentrasi Kosarine.

Sama halnya pada pertambahan tinggi tanaman, karena perlakuan yang diberikan berupa kosarine yang berasal dari urine sapi, yang mengandung hormon IAA, maka konsentrasi yang digunakan berperan mempengaruhi pertumbuhan bibit tanaman tergantung keperluan fase pertumbuhan dan perkembangan tanaman, yang ada kaitannya dengan hormon endogen dalam tanaman itu sendiri.

Pada semua umur bibit pisang, pengaruh perlakuan konsentrasi kosarine baik berpengaruh nyata atau tidak, memperlihatkan tendensi bahwa perlakuan $\mathrm{K} 1$ (10 ml/L air) menunjukan hasil pertambahan jumlah daun terbanyak. Namun pada konsentrasi tinggi pengaruhnya hasil menurun. Keadaan ini sesuai dengan sifat fisiologi dari hormon tumbuh seperti yang dinyatakan Wattimena (1988), bahwa dalam konsentrasi yang rendah dapat merangsang pertumbuhan, sebaliknya dalam konsentrasi yang tinggi bersifat menghambat pertumbuhan. 
Pada titik tumbuh tanaman yang merupakan jaringan meristematis, terdiri dari selsel meristem, senantiasa membelah diri kemudian berdiferensiasi untuk meningkatkan tinggi tanaman atau jumlah daun. Oleh karena itu dengan diberikan hormon eksogen yang tepat dapat meningkatkan organ tanaman. Sesuai yang dinyatakan oleh Wareing and Phillips (1981), untuk proses morphogenesis tanaman diperlukan hormon tumbuh dalam konsentrasi yang tepat.

\section{Pertambahan Panjang Daun Terpanjang Bibit Pisang Cavendish}

Hasil sidik ragam menunjukan bahwa perlakuan konsentrasi Pupuk Organik Cair (POC) Kosarine berpengaruh nyata terhadap pertambahan panjang daun terpanjang bibit pisang cavendish asal kultur jaringan di nurseri pada umur 3 MST dan 9 MST, namun berpengaruh tidak nyata pada umur 5 MST dan 7 MST. Rata-rata pertambahan panjang daun terpanjang bibit dapat dilihat pada Tabel 3.

Tabel 3. Rata-rata Pertambahan Panjang Daun Terpanjang Bibit Pisang Ekspor Cavendish Asal Kultur Jaringan di Nurseri dengan Teknologi Pemberian Berbagai Konsentrasi Kosarine (cm).

\begin{tabular}{ccccc}
\hline Perlakuan Konsentrasi & \multicolumn{4}{c}{ Pertambahan Tinggi Bibit Pada Umur } \\
\cline { 2 - 4 } Kosarine $(\mathrm{K})$ & $3 \mathrm{MST}$ & $5 \mathrm{MST}$ & $7 \mathrm{MST}$ & $9 \mathrm{MST}$ \\
\hline $\mathrm{K} 0(0 \mathrm{ml} / \mathrm{L}$ air $)$ & $3.40 \mathrm{a}$ & 9.37 & 10.15 & $11.20 \mathrm{a}$ \\
$\mathrm{K} 1(10 \mathrm{ml} / \mathrm{L}$ air $)$ & $6.02 \mathrm{~b}$ & 10.27 & 11.13 & $12.52 \mathrm{~b}$ \\
$\mathrm{~K} 2(20 \mathrm{ml} / \mathrm{L}$ air $)$ & $5.67 \mathrm{~b}$ & 9.83 & 10.45 & $11.28 \mathrm{a}$ \\
$\mathrm{K} 3(30 \mathrm{ml} / \mathrm{L}$ air $)$ & $5.02 \mathrm{~b}$ & 8.12 & 8.83 & $9.77 \mathrm{a}$ \\
\hline
\end{tabular}

Ket : Angka-angka yang diikuti oleh huruf yang sama pada jalur yang sama berarti tidak berbeda sama.

Dari Tabel 3 tampak bahwa pengaruh konsentrasi kosarine berpengaruh nyata terhadap pertambahan panjang daun terpanjang bibit pisang cavendish asal kultur jaringan di nurseri pada umur 3 MST dan 9 MST. Pada umur 3 MST perlakuan K1 (10 $\mathrm{ml} / \mathrm{L}$ air) tidak berbeda nyata dengan $\mathrm{K} 2(20 \mathrm{ml} / \mathrm{L}$ air $)$ dan $\mathrm{K} 3(30 \mathrm{ml} / \mathrm{L}$ air $)$, namun ketiganya berbeda nyata dengan kontrol (K0). Pada umur 9 MST perlakuan K1 (10 ml/L air) berbeda nyata dengan $\mathrm{K} 0, \mathrm{~K} 2$ dan $\mathrm{K} 3$, namun $\mathrm{K} 0, \mathrm{~K} 2$ dan $\mathrm{K} 3$ tidak saling berbeda nyata.

Pada umur 5 MST dan 7 MST pengaruh perlakuan konsentrasi kosarine terhadap pertambahan panjang daun terpanjang bibit pisang asal kultur jaringan tidak berpengaruh nyata. Namun masih tampak pada data perlakuan yang terbaik pada konsentrasi K1 (10 $\mathrm{ml} / \mathrm{L}$ air), dibandingkan perlakuan lainnya.

Dari semua data pada Tabel 3 pengaruh konsentrasi kosarine pada pertambahan panjang daun pada semua umur pengamatan 3, 5, 7 dan 9 MST baik yang nyata atau tidak, bertendensinya perlakuan $\mathrm{K} 1$ (10 ml/L air) yang terbaik, namun dengan semakin meningkatnya konsentrasi yang diberikan hasilnya semakin menurun.

Pertumbuhan dan perkembangan panjang daun bibit pisang cavendish asal kultur jaringan di nurseri dengan perlakuan berbagai konsentrasi kosarine, mulai umur 3 sampai 9 MST, terlihat pada Gambar 3. Hal ini diduga karena pupuk organik cair kosarine selain 
mengandung unsur hara makro dan mikro yang dibutuhkan untuk pertumbuhan tanaman juga mengandung hormon tumbuh IAA yang dapat mengatur proses pembelahan dan pembesaran sel sesuai dengan fase-fase pertumbuhan tanaman, seperti pemanjangan daun. Sesuai yang dinyatakan Abidin (1983), Indole Acetie Acid (IAA) adalah hormon tumbuh golongan auksin yang berperan dalam proses pembesaran dan pemanjangan sel. Hormon tumbuh tersebut dapat bersifat menstimulir pertumbuhan bila dalam konsentrasi yang tepat, namun bila berlebihan bersifat menghambat atau mematikan.

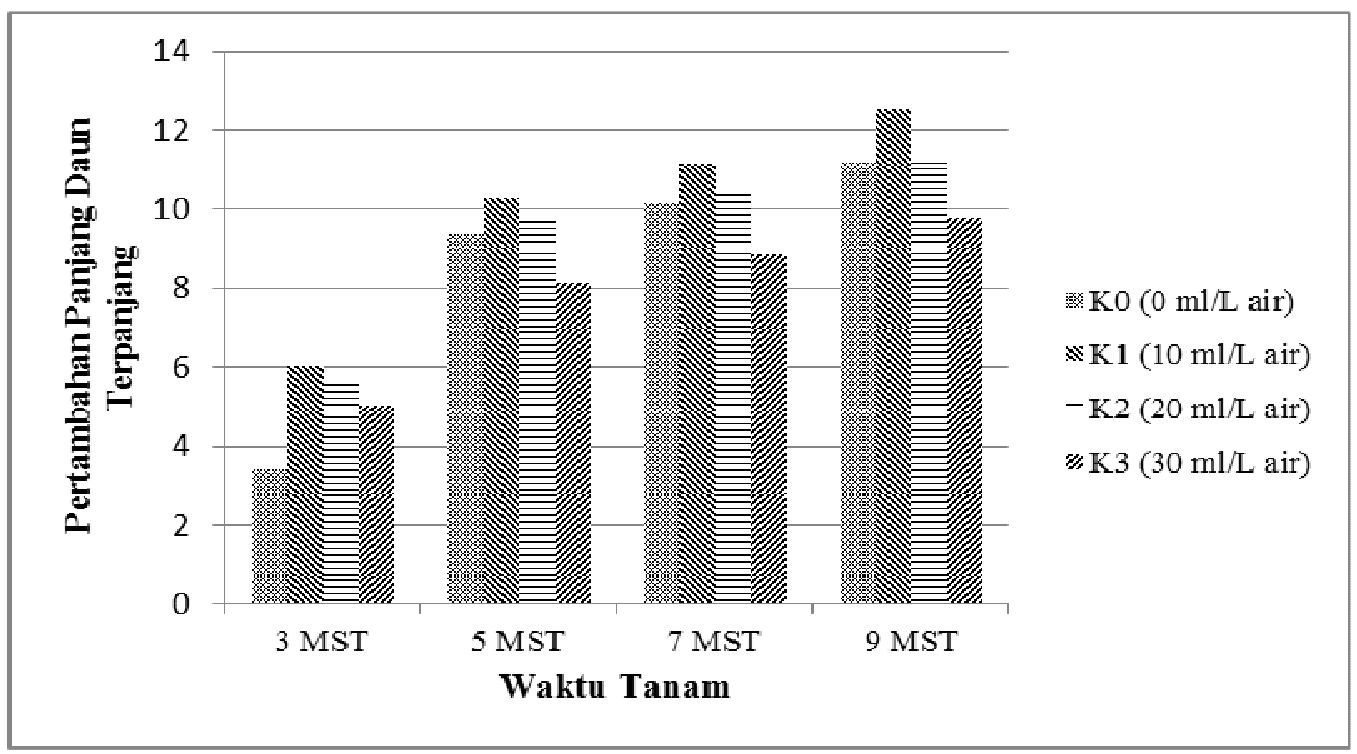

Gambar 3. Histogram Rata-rata Pertambahan Panjang Daun Terpanjang Bibit Pisang Ekspor Cavendish Asal Kultur Jaringan di Nurseri dengan Teknologi Pemberian Berbagai Konsentrasi Kosarine.

Bibit pisang asal kultur jaringan ini diduga masih mengandung hormon tumbuh sewaktu diinduksi untuk beregenerasi di laboratorium, sehingga dengan perlakuan konsentrasi kosarine yang mengandung nutrisi dan auksin IAA. K1 (10 ml/L air) sudah menunjukan pertumbuhan yang terbaik dibandingkan pada konsentrasi yang lebih tinggi. Auksin berperan untuk menginduksi akar, sedangkan akar berfungsi untuk menyerap nutrisi yang tersedia pada media tumbuh sehingga pertumbuhan dan perkembangan tanaman lebih seperti organ daun. Sesuai yang dinyatakan Sari (2016), bahwa ada korelasi positif antara jumlah akar dan pertumbuhan tanaman semakin banyak jumlah akar yang dihasilkan maka unsur hara yang diserap tanaman juga semakin banyak, sehingga pertumbuhan tanaman juga semakin baik.

\section{Pertambahan Lebar Daun Terlebar Bibit Pisang Cavendish}

Hasil sidik ragam menunjukan bahwa perlakuan konsentrasi Pupuk Organik Cair (POC) Kosarine berpengaruh nyata terhadap pertambahan lebar daun terlebar bibit pisang Cavendish asal kultur jaringan di nurseri pada umur 3, 5, 7, dan 9 Minggu Setelah Tanam (MST). Rata-rata pertambahan tinggi bibit dapat dilihat pada Tabel 4. 
Tabel 4. Rata-rata Pertambahan Lebar Daun Terlebar Bibit Pisang Ekspor Cavendish Asal Kultur Jaringan di Nurseri dengan Teknologi Pemberian Berbagai Konsentrasi Kosarine (cm).

\begin{tabular}{ccccc}
\hline Perlakuan Konsentrasi & \multicolumn{4}{c}{ Pertambahan Tinggi Bibit Pada Umur } \\
\cline { 2 - 4 } Kosarine $(\mathrm{K})$ & $3 \mathrm{MST}$ & $5 \mathrm{MST}$ & $7 \mathrm{MST}$ & $9 \mathrm{MST}$ \\
\hline $\mathrm{K} 0(0 \mathrm{ml} / \mathrm{L}$ air $)$ & $1.42 \mathrm{a}$ & $4.35 \mathrm{a}$ & $5.40 \mathrm{a}$ & $5.80 \mathrm{a}$ \\
$\mathrm{K} 1(10 \mathrm{ml} / \mathrm{L}$ air $)$ & $3.78 \mathrm{~b}$ & $5.72 \mathrm{~b}$ & $6.48 \mathrm{~b}$ & $6.98 \mathrm{~b}$ \\
$\mathrm{~K} 2(20 \mathrm{ml} / \mathrm{L}$ air $)$ & $3.32 \mathrm{~b}$ & $5.13 \mathrm{a}$ & $5.87 \mathrm{a}$ & $6.32 \mathrm{a}$ \\
$\mathrm{K} 3(30 \mathrm{ml} / \mathrm{L}$ air $)$ & $2.72 \mathrm{~b}$ & $4.70 \mathrm{a}$ & $5.48 \mathrm{a}$ & $6.17 \mathrm{a}$ \\
\hline
\end{tabular}

Ket : Angka-angka yang diikuti oleh huruf yang sama pada jalur yang sama berarti tidak berbeda sama.

Dari Tabel 4 tampak bahwa perlakuan konsentrasi kosarine berpengaruh nyata terhadap pertambahan lebar daun terlebar bibit pisang cavendish asal kultur jaringan di nurseri pada umur 3, 5, 7, dan 9 Minggu Setelah Tanam (MST). Pada umur 3 MST, pengaruh perlakuan $\mathrm{K} 1$ (10 ml/L air), K2 (20 ml/L air) dan K3 (30 ml/L air) berbeda nyata dengan kontrol $\mathrm{K} 0(0 \mathrm{ml} / \mathrm{L}$ air), namun $\mathrm{K} 1, \mathrm{~K} 2$ dan $\mathrm{K} 3$ ketiga perlakuan tersebut tidak saling berbeda nyata. Pada umur 5 MST, 7 MST dan 9 MST, pengaruh perlakuan K1 (10 $\mathrm{ml} / \mathrm{L}$ air) berbeda nyata dengan kontrol $(0 \mathrm{ml} / \mathrm{L}$ air), $\mathrm{K} 2(20 \mathrm{ml} / \mathrm{L}$ air) dan $\mathrm{K} 3(30 \mathrm{ml} / \mathrm{L}$ air). Namun antara ketiganya K0, K2 dan K3 tidak saling berbeda nyata.

Dari data pada tabel ini terlihat bahwa pengaruh perlakuan $\mathrm{K} 1$ menunjukan perlakuan yang terbaik yang dapat memberikan hasil pertambahan lebar daun yang terlebar pada bibit pisang pada semua umur pengamatan dibandingkan perlakuan lain. Dengan semakin meningkatnya konsentrasi kosarine yang diberikan melebihi $10 \mathrm{ml} / \mathrm{L}$ air memberikan pengaruh hasil yang semakin menurun.

Pertumbuhan dan perkembangan lebar daun bibit pisang cavendish asal kultur jaringan di nurseri dengan pemberian berbagai konsentrasi kosarine, mulai umur 3 sampai 9 MST, terlihat pada Gambar 4.

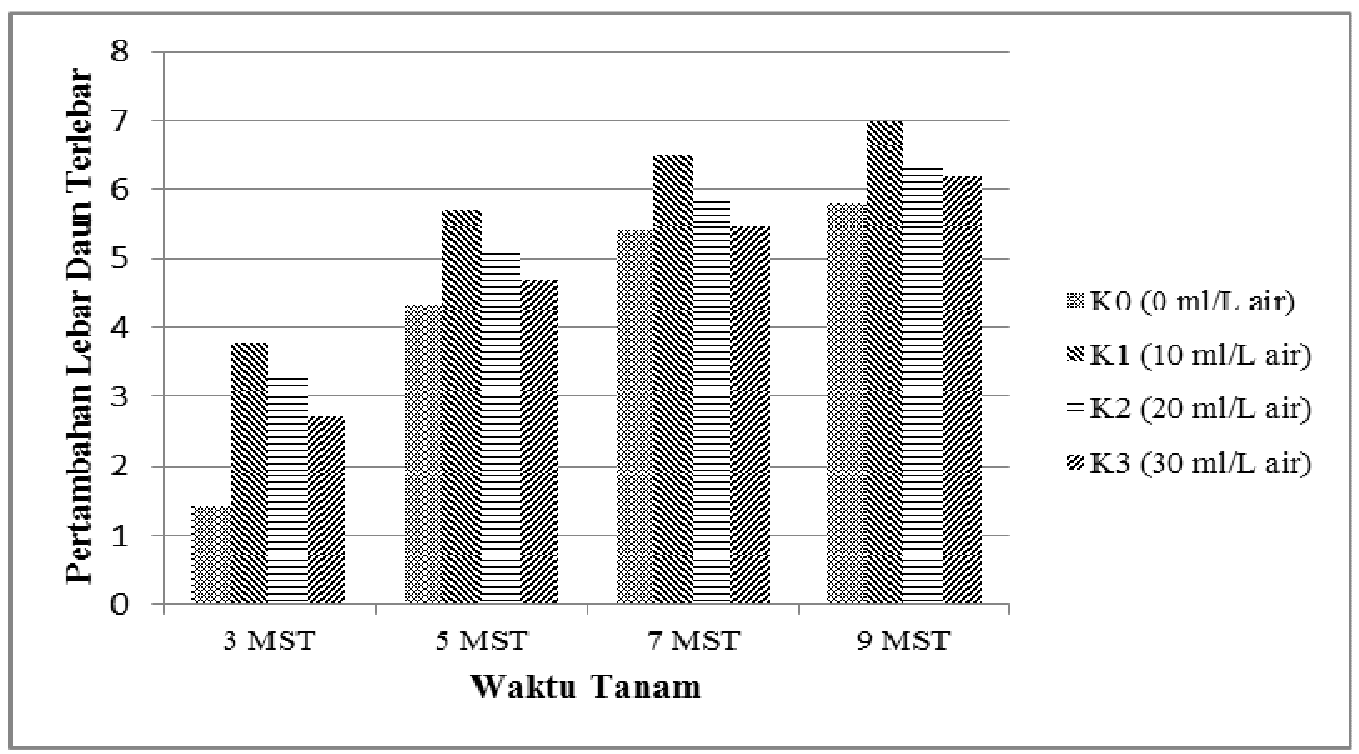

Gambar 4. Histogram Rata-rata Pertambahan Lebar Daun Terlebar Bibit Pisang Ekspor Cavendish Asal Kultur Jaringan di Nurseri dengan Teknologi Pemberian Berbagai Konsentrasi Kosarine. 
Hal ini diduga karena pupuk organik cair kosarine yang mengandung unsur hara makro dan mikro yang dapat memenuhi kebutuhan nutrisi tanaman, selain itu juga mengandung hormon tumbuh Indole Acetie Acid yang berperan membantu pembesaran dan pemanjangan sel setelah proses pembelahan sel, sehingga pertumbuhan daun semakin melebar. Sesuai dengan pendapat Dwijoseputro (1994), dengan tersediaanya unsur hara dan ZPT yang cukup, maka aktivitas metabolisme tanaman dapat berlanjut dengan baik dan cepat, sehingga pertumbuhan organ tanaman seperti daun akar meningkat. Sebaliknya jika dalam konsentrasi yang tinggi atau berlebihan dapat menghambat pertumbuhan (Wattimena, 1988).

\section{Pertambahan Diameter Batang Bibit Pisang Cavendish}

Hasil sidik ragam menunjukan bahwa perlakuan konsentrasi Pupuk Organik Cair (POC) Kosarine berpengaruh nyata terhadap pertambahan diameter batang bibit pisang Cavendish asal kultur jaringan di nurseri pada umur 9 Minggu Setelah Tanam (MST). Rata-rata pertambahan tinggi bibit dapat dilihat pada Tabel 5.

Tabel 5. Rata-rata Pertambahan Diameter Batang Bibit Pisang Ekspor Cavendish Asal Kultur Jaringan di Nurseri dengan Teknologi Pemberian Berbagai Konsentrasi Kosarine (cm).

\begin{tabular}{cc}
\hline Perlakuan Konsentrasi & Pertambahan Tinggi Bibit Pada Umur \\
\cline { 2 - 2 } Kosarine $(\mathrm{K})$ & $\mathrm{IX}$ \\
\hline K0 $(0 \mathrm{ml} / \mathrm{L}$ air $)$ & $1,73^{\mathrm{a}}$ \\
$\mathrm{K} 1(10 \mathrm{ml} / \mathrm{L}$ air $)$ & $2,48^{\mathrm{b}}$ \\
$\mathrm{K} 2(20 \mathrm{ml} / \mathrm{L}$ air $)$ & $2,23^{\mathrm{b}}$ \\
$\mathrm{K} 3(30 \mathrm{ml} / \mathrm{L}$ air $)$ & $2,03^{\mathrm{a}}$ \\
\hline
\end{tabular}

Dari Tabel 5 tampak bahwa perlakuan konsentrasi kosarine berpengaruh nyata terhadap pertambahan diameter batang bibit pisang cavendish asal kultur jaringan di nurseri pada umur 9 MST, sehingga dilanjutkan dengan uji BNT 5\%. Perlakuan K1 (10 $\mathrm{ml} / \mathrm{L}$ air) tidak berbeda nyata dengan $\mathrm{K} 2$ (20 ml/L air), namun keduanya berbeda nyata dengan $\mathrm{KO}(0 \mathrm{ml} / \mathrm{L}$ air) dan $\mathrm{K} 3$ (30 ml/L air), sedangkan $\mathrm{K} 0$ (kontrol) tidak berbeda nyata dengan K3. Perlakuan K0 menghasilkan pertambahan diameter $1,73 \mathrm{~cm}$, K1 menghasilkan 2,48 cm, K2 menghasilkan 2,23 dan K3 menghasilkan 2,03 cm. Dari semua perlakuan ini $\mathrm{K} 1$ menghasilkan pertambahan diameter yang tertinggi yaitu 2,48 $\mathrm{cm}$. Tampak dari tabel data tersebut, semakin meningkatnya konsentrasi kosarine yang diberikan lebih dari $10 \mathrm{ml} / \mathrm{L}$ air, memberikan hasil pertambahan diameter batang yang semakin menurun, walaupun hasilnya masih lebih baik dibandingkan kontrol.

Pertumbuhan dan perkembangan diameter batang bibit pisang cavendish asal kultur jaringan yang dihasilkan pada umur 9 Minggu Setelah Tanam (MST) di nurseri, terlihat pada Gambar 5. Hal ini diduga untuk pertumbuhan diameter batang tanaman diperlukan banyak energi yang berasal dari proses fotosintesa untuk merubah bahan anorganik yang diserap akan dari media tumbuhnya, menjadi bahan organik sebagai penyusun struktur tubuh tanaman seperti batang. Dengan diberikannya pupuk kosarine 
yang mengandung unsur hara makro dan mikro serta hormon tumbuh IAA maka pertumbuhan tanaman akan lebih baik lagi. Sebenarnya hormon tumbuh bukanlah hara, tetapi mempercepat bahan organik yang berperan dalam proses pertumbuhan dan perkembangan tanaman, asal konsentrasinya tepat, bila berlebihan bersifat menghambat. Seperti yang dinyatakan Heddy (1996), bahwa hormon tidak sama dengan pupuk, sebab hormon sama sekali tidak akan memberikan unsur hara pada tanaman, tetapi hormon berperan dalam mengatur berbagai proses fisiologi, seperti: pembelahan dan pemanjangan sel, pertumbuhan akar, batang, daun, bunga dan buah.

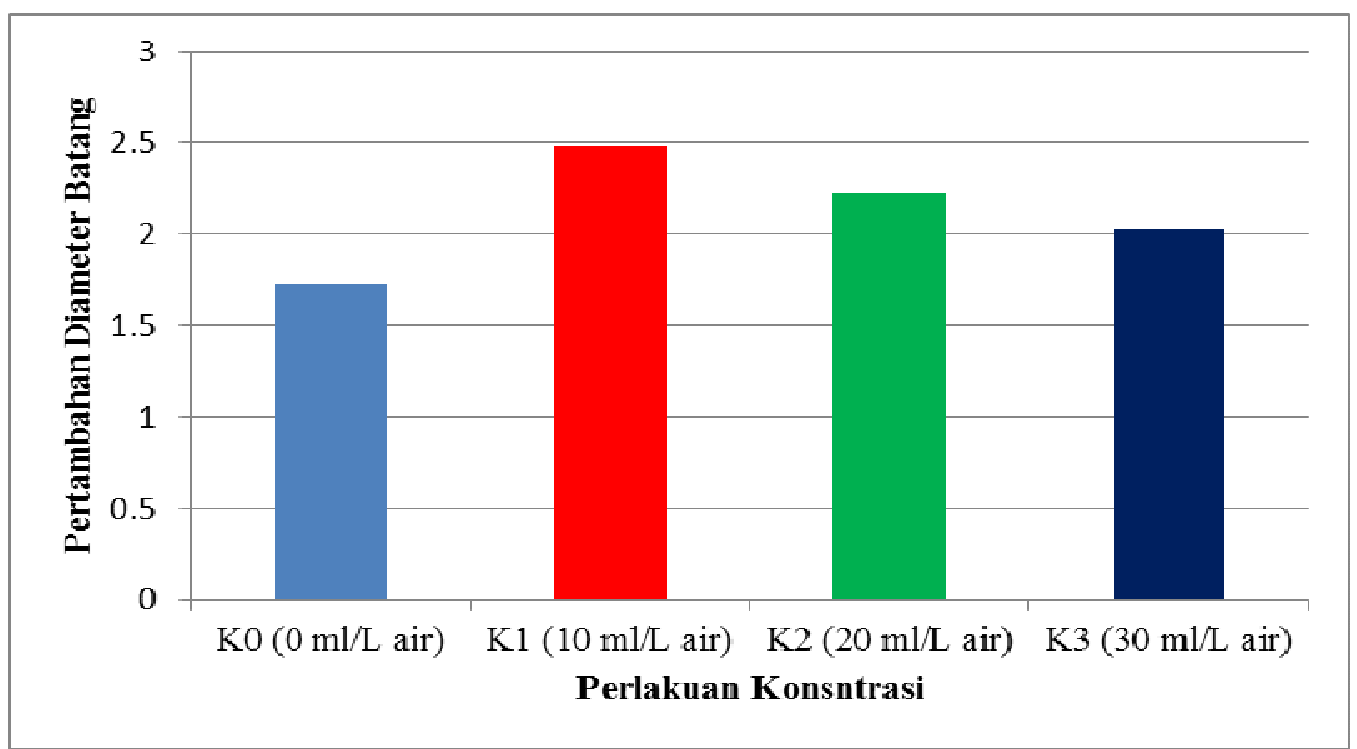

Gambar 5. Histogram Rata-rata Pertambahan Diameter Batang Bibit Pisang Ekspor Cavendish Asal Kultur Jaringan di Nurseri dengan Teknologi Pemberian Berbagai Konsentrasi Kosarine.

\section{$4 \quad$ Kesimpulan}

Pengaruh berbagai konsentrasi pupuk organik cair kosarine terhadap semua variabel pengamatan, pertumbuhan bibit pisang cavendish asal kultur jaringan di nurseri, baik yang berpengaruh nyata maupun yang tidak nyata bertendensi memberikan hasil yang terbaik pada perlakuan K1 (10 ml/L air) pada pertambahan tinggi, jumlah daun, pertambahan panjang daun terpanjang, lebar daun terlebar dan diameter batang bibit pisang pada semua umur pengamatan 3, 5, 7 dan 9 MST. Dari hasil penelitian ini dapat disarankan untuk memacu pertumbuhan bibit pisang cavendish asal kultur jaringan yang terbaik dengan konsentrasi $10 \mathrm{ml} / \mathrm{L}$ air.

\section{Daftar Pustaka}

Abidin, Z. 1983. Dasar-dasar Pengetahuan Tentang Zat Pengatur Tumbuh. Penerbit Angkasa Bandung. Bandung.

Dwijoseputro, D. 1994. Pengantar Fisiologi Tumbuhan. Gramedia. Jakarta

Heddy, S. 1996. Hormon Tumbuhan. Raja Grafindo Persada. Jakarta. 
Nirmala R. 2013 The Effect of Concentration of Kosarine Organic Liquid Fertilizer on the Growth and Yield (Lactuca satifa L) Agrin yournal Vol 17, No 2. ISSN, 1410-0029 Purwokerto

Sari, Y.P. 2016. Pengembangan dan Potensi Metabolit Sekunder Tumbuhan Sarang Semut (Myrmecodia tuberosa) Dengan Metode Kultur Jaringan. Disertasi Program Doktor Ilmu Kehutanan. Program Pasca Sarjana Fahutan Unmul. Samarinda

Shanti, R. 2015. Klasifikasi Tanah dan Sistem Lahan. Fakultas Pertanian Universitas Mulawarman. Samarinda

Suhardiman, P 1997. Budidaya pisang Cavendish. Penerbit Konisius Jogyakarta.

Suharman, A. R. 2008. Pengaruh Konsentrasi Urin Sapi dan Penggunaan Benih terhadap Pertumbuhan dan Hasil Tanaman Bawang Tiwai (Eleutherine americana L. Merr) Skripsi Faperta Unmul

Wareing, P. F. And I. D. J. Phillips 1981. Growth And Differentiation In Plant. Pergamon LED.England

Wattimena, G.A. 1988. Zat Perangsang Tumbuh Tanaman. PAU-IPB. Bogor.

Wong, K. F., Suhaimi, O. And Fatimah, K., 2016. On-Farm Grower-Friendly Nursery Technique Acclimatization Of Tissue-Cultured Banana Seedlings. International Seminar Regional Network Poverty Eradication (Renper) Bangladesh Agricultural University Mymensingh, Bangladesh. 